\title{
ANALISIS BEBERAPA UNSUR KIMIA KOMPOS Azolla mycrophylla
}

\author{
SRI UTAMI LESTARI, MURYANTO \\ Fakultas Pertanian Universitas Lancang Kuning \\ Jl.Yos Sudarso Km.8 Rumbai Pekanbaru
}

\begin{abstract}
The most consumed part of the plants is the leaf part so that the fertilizer provided should contain high nitrogen $(\mathrm{N})$. The nature of the $\mathrm{N}$ fertilizer is volatile and when the rainy season there can be washing. When plants deficienci nutrients shows symtoms of yellowing leaves so that the application of $\mathrm{N}$ fertilizer to the plant must remain unfulfilled. Azolla is a usable alternative. Azolla has a high $\mathrm{N}$ nutrient content because it is symbiotic with anabaena in binding to free nitrogen in the air.

The purpose of this study was to determine the chemical composition (pH,N,P,K) Azolla mycrophylla. The experiment was conducted experimentally with the first stage of composting azolla after it was done chemical analysis in the laboratory. The result of this research can be concluded that chemical analysis of Azolla mycrophylla cpmpost is as follows :pH 7,17, N 2,57\%, P 0,34\%, K 0,03\%.
\end{abstract}

\section{Keyword : compost, azolla}

\begin{abstract}
ABSTRAK
Bagian tanaman sayuran yang paling banyak dikonsumsi adalah bagian daun sehingga pupuk yang diberikan sebaiknya mengandung nitrogen $(\mathrm{N})$ tinggi. Sifat pupuk $\mathrm{N}$ mudah menguap dan ketika musim penghujan dapat terjadi pencucian. Ketika tanaman kekurangan unsur hara nitrogen menunjukkan gejala daun menguning, sehingga pengaplikasian pupuk $\mathrm{N}$ kepada tanaman harus tetap terpenuhi.Azolla merupakan alternative yang dapat digunakan.Azolla memiliki kandungan unsur hara $\mathrm{N}$ yang tinggi karena bersimbiosis dengan Anabaena dalam mengikat nitrogen bebas di udara.

Tujuan dilakukannya penelitian ini adalah untuk mengetahui komposisi kimia $(\mathrm{pH}$, N,P,K) kompos Azolla mycrophylla. Penelitian dilaksanakan secara eksperimen dengan tahapan awal pembuatan kompos azolla setelah itu dilakukan analisis kimia di laboratorium. Hasil penelitian dapat disimpulkan bahwa analisis kimia ( $\mathrm{pH}, \mathrm{N}, \mathrm{P}, \mathrm{K})$ kompos Azolla mycrophyllaadalah sebagai berikut :pH 7,17, N 2,57\%, P 0,34\%, K 0,03\%.
\end{abstract}

\section{Kata Kunci : kompos, azolla}

\section{PENDAHULUAN}

\section{Latar Belakang Masalah}

Pemakaian pupuk anorganik secara berlebihan dalam bidang pertanian dan secara terus menerus dapat mencemari lingkungan. Disatu sisi harga pupuk an organik semakin hari semakin mahal dan disisi lain diperlukanadanya peningkatan produksi pertanian guna memenuhi kebutuhan pangan masyarakat. Tingkat konsumsi pupuk anorganik juga semakin tinggi sementara bahan baku pupuk semakin menipis.

Menurut Indriani (2004) pupuk an organik dapat menimbulkan ketergantungan dan dapat membawa dampak kurang baik misalnya tanah menjadi rusak akibat penggunaan yang 
berlebihan dan terus-menerus akan menyebabkan tanah menjadi keras, air tercemar dan keseimbangan alam akan terganggu.

Oleh karena itu diperlukan asupan unsur hara yang bisa mengefisienkan pemakaian pupuk anorganik dan aman bagi lingkungan. Banyak tumbuhan disekitar yang dapat dimanfaatkan sebagai sumber $\mathrm{N}$ salah satunya Azolla pinnata yang memiliki $\mathrm{N}$ cukup tinggi. Azolla pinnata mengandung $\mathrm{N} 2,55-3,95 \%$ (Laboratorium Bioteknologi Pertanian UMM, 2003).

Tanaman sayuran merupakan salah satu komoditi horikultura yang memiliki prospek dan nilai komersial yang cukup baik. Meningkatnya kesadaran penduduk akan kebutuhan gizi menyebabkan bertambahnya permintaan akan sayuran. Kandungan gizi pada sayuran terutama vitamin dan mineral tidak dapat disubstitusi melalui makanan pokok (Nazaruddin, 2003)

Bagian tanaman sayuran yang paling banyak dikonsumsi adalah bagian daun sehingga pupuk yang diberikan sebaiknya mengandung nitrogen (N) tinggi. Sifat pupuk $\mathrm{N}$ mudah menguap dan ketika musim penghujan dapat terjadi pencucian. Ketika tanaman kekurangan unsur hara nitrogen menunjukkan gejala daun menguning, sehingga pengaplikasian pupuk $\mathrm{N}$ kepada tanaman harus tetap terpenuhi.

Menurut Sarief (1986) bahwa ketersediaan nutrisi yang cukup yang dapat diserap untuk pertumbuhan tanaman merupakan salah satu factor yang dapat mempengaruhi hasil. Ketersediaan hara dalam tanah sangat dipengaruhi oleh adanya bahan organic. Hakim et al (1986) menyatakan bahwa bahan organik merupakan bahan penting dalam kesuburan tanah. Secara garis besar bahan organik memperbaiki sifat-sifat tanah meliputi sifat fisik, kimia dan biologi tanah.

Andrew (1998) dalam Putra et al (2013) menyatakan bahwa ketika bahan organik yang diaplikasikan mengandung banyak nitrogen maka mikroorganisme tersebut menggunakan nitrogen untuk hidup. Terkadang mikroorganisme melepaskan nitrogen yang berlebih kedalam tanah dalam bentuk ammonia. Pada lahan pertanian yang mengandung rendah bahan organik maka mikroorganisme dalam tanah menggunakan atau mengkonsumsi nitrogen untuk memenuhi kehidupannya tanpa melepaskan nitrogen kedalam tanah yang sangat berfungsi bagi tanaman. Azolla merupakan alternative yang dapat digunakan.Azolla memiliki kandungan unsur hara $\mathrm{N}$ yang tinggi karena bersimbiosis dengan Anabaena dalam mengikat nitrogen bebas di udara.

\section{Rumusan Masalah}

Azolla mempunyai keunggulan dibandingkan kompos yang lain yaitu kandungan unsur hara lebih tinggi dari pada kompos lain (kompos sampah kota, kompos rumput atau kompos gulma) atau POC biasa sehingga pemakaiannya lebih sedikit. Penggunaan pupuk organik yaitupupuk-pupuk yang berasal dari bahan organik merupakan alternative tepat yang dapat dilakukan untuk mengurangi dampak penggunaan pupuk kimia. Oleh karena itu pemanfaatan azolla sebagai pupuk organik akan menghemat penggunaan pupuk anorganik disamping menjaga keseimbangan hara dalam tanah. Ditinjau dari segi kimia tanah, azolla dapat memperkaya unsur hara makro dan mikro dalam tanah, untuk itu komposisi kimia yang dikandung kompos azolla perlu diteliti.

\section{Tujuan Penelitian}

Adapun tujuan dilakukannya penelitian ini adalah untuk mengetahui komposisi kimia $(\mathrm{pH}, \mathrm{N}, \mathrm{P}, \mathrm{K})$ kompos Azolla mycrophylla

Penelitian dilaksanakan secara eksperimen dengan tahapan awal pembuatan kompos azolla setelah itu dilakukan analisis kimia di laboratorium dengan tahapan sebagai berikut : 
1. Pembuatan Kompos Azolla

Cara pembuatan kompos azolla dapat dilakukan dengan langkah-langkah sebagai berikut :

- Siapkan drum

- Cacah tumbuhan azolla menjadi bagian kecil-kecil

- Taburkan dedak pada cacahan azolla dengan merata

- Campurkan decomposer dan molase dengan air dalam satu botol (35\% EM-4 molase $15 \%$ dan air $50 \%$ aduk lalu semprotkan hingga basah)

- Biarkan selama 12 - 15 hari dengan tetap menjaga kelembaban kompos dan mengaduk kompos agar terjadi penguraian secara merata

- Kompos azolla dapat dipanen dan diangin-anginkan terlebih dahulu untuk mengurangi kelembaban kompos

2. Pengeringan Kompos

Kompos azolla yang sudah matang kemudian dikeringanginkan guna mempermudah dalam pengangkutan, dan analisa kimia.

3. Analisis Kimia Kompos Azolla

Analisis komposisi kimia azolla adalah sebagai berikut :

\begin{tabular}{|l|l|l|}
\hline \multicolumn{1}{|c|}{ No } & \multicolumn{1}{|c|}{ Analisis Kimia } & \multicolumn{1}{c|}{ Metode } \\
\hline 1. & $\mathrm{pH} \mathrm{H} \mathrm{H}_{2} \mathrm{O}$ & $\mathrm{pH}$ meter \\
\hline 2. & $\mathrm{~N}$ total $(\%)$ & Kjedhal \\
\hline 3. & $\mathrm{P}$ tersedia $(\mathrm{ppm})$ & Bray 1 \\
\hline 4. & $\mathrm{~K} \mathrm{dd}(\mathrm{me} / 100 \mathrm{~g})$ & $\mathrm{N} \mathrm{NH}_{4} \mathrm{OA}_{c} \mathrm{pH} 7,0$ \\
\hline
\end{tabular}

\section{HASIL DAN PEMBAHASAN}

Hasil analisis kimia yang dilakukan terhadap kompos azolla dari beberapa analisis kimia yang

Tabel 1. Analisis Kimia (pH,N,P,K) Kompos Azolla mycrophylla

\begin{tabular}{|l|l|l|r|}
\hline \multicolumn{1}{|c|}{ No } & \multicolumn{1}{|c|}{ Analisis Kimia } & \multicolumn{1}{|c|}{ Metode } & \multicolumn{1}{c|}{ Hasil Analisis } \\
\hline 1. & $\mathrm{pH}$ & $\mathrm{pH}$ meter & 7,17 \\
\hline 2. & N total $(\%)$ & Kjedahl & 2,57 \\
\hline 3. & P tersedia $(\mathrm{ppm})$ & Bray-1 & 342,025 \\
\hline 4. & K-dd $(\mathrm{me} / 100 \mathrm{~g})$ & $\mathrm{N} \mathrm{NH}_{4} \mathrm{Oac} \mathrm{pH} 7.0$ & 86,57 \\
\hline
\end{tabular}

Kandungan unsur hara dalam pupuk organik jauh lebih rendah dari pada yang ada didalam pupuk buatan. Cara aplikasinya juga lebih sulit karena pupuk

organik dibutuhkan dalam jumlah yang lebih besar dari pada pupuk kimia serta tenaga kerja yang diperlukan juga lebih banyak. Namun, hingga saat ini fungsi pupuk organik belum tergantikan oleh dilakukan terangkum dalam tabel dibawah ini : 


\begin{tabular}{|l|l|r|r|r|}
\hline & Analisis Kimia & Kompos Azolla & Pukan Ayam * & Pukan Sapi* \\
\hline 1. & N total (\%) & 2,57 & 1,7 & 0,3 \\
\hline 2. & P tersedia (\%) & 0,34 & 1,9 & 0,2 \\
\hline 3. & K-dd (\%) & 0,03 & 1,5 & 0,3 \\
\hline
\end{tabular}

- Sumber : Hardjowigeno, 1995

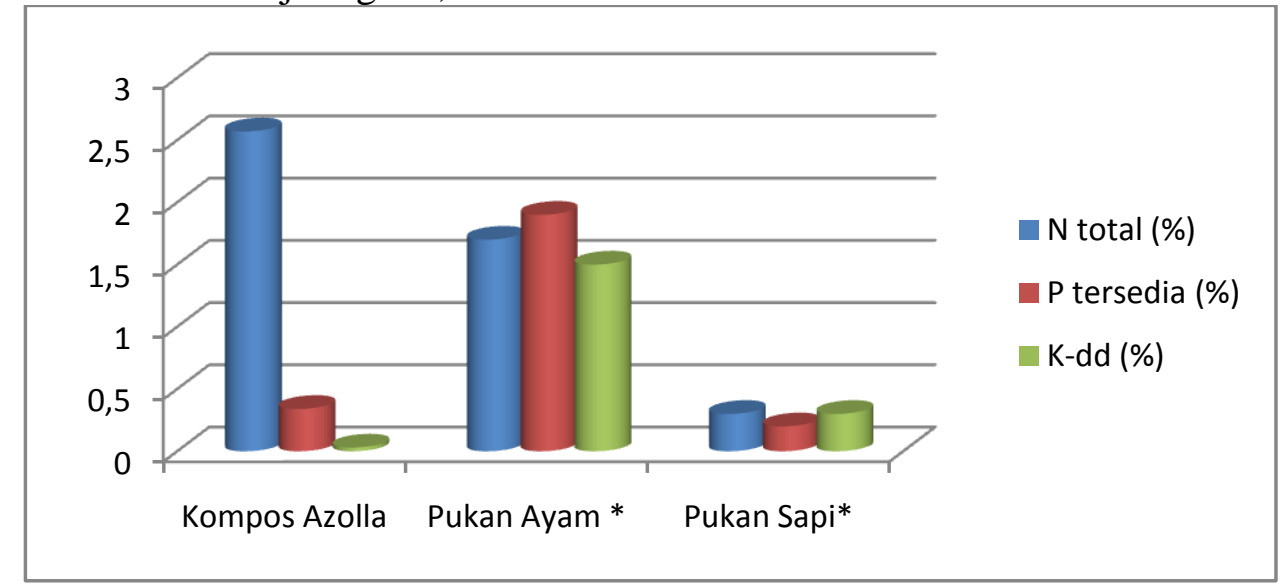

Gambar 1. Grafik Komposisi Kimia NPK (Kompos Azolla, Pukan Ayam dan Pukan Sapi) 
Hasil analisis diatas menunjukkan bahwa Azolla mycrophylla dapat digunakan sebagai pupuk. Dari hasil penelitian pembuatan kompos Azolla merupakan kompos yang sangat cepat terurai, dalam waktu 2 minggu kompos sudah siap digunakan untuk itu Azolla dapat digunakan dengan membenamkannya secara langsung kedalam tanah. Hal ini sesuai dengan Fitra (2015) bahwa Azolla sp dapat

Berdasarkan komposisi kimia azolla sangat efektif digunakan sebagai pupuk organik untuk memperbaiki struktur tanah juga kandungan $\mathrm{N}, \mathrm{P}, \mathrm{K}$ yang sangat tinggi pada azolla. dibandingkan sumber Kandungan hara yang tinggi dapat mempengaruhi pertumbuhan vegetative tanaman seperti daun. Salah satu indikator pertumbuhan dan perkembangan tanaman adalah parameter daun. Menurut Guritno (1995) dalam Huda, Widaryanto dan Nugroho (2016) menyatakan bahwa parameter daun sangat diperlukan selain sebagai indicator pertumbuhan

Hasil analisispH kompos azolla yang netral dan cenderung basa sangat efektif dalam menetralkan tanah. Salah satu keunggulan kompos dibandingkan dengan pupuk kimia adalah kompos tidak menurunkan $\mathrm{pH}$ tanah dan tidak terlarut air sehingga dosis penggunaan kompos pada penanaman kedepan bisa diturunkan bahkan pengapuran tidak diperlukan apabila kadar penggunaan kompos sangat besar sehingga kompos sangat efektif dalam menetralkan $\mathrm{pH}$ tanah. Suntoro (2003) melaporkan bahwa penambahan bahan organik pada digunakan dengan membenamkannya secara langsung kedalam tanah. Dengan cara demikian dapat menghemat pupuk Urea $60-80 \%$ dari total kebutuhan pertumbuhan padi. Lebih lanjut BATAN (2010) menambahkan bahwa penggunaan azolla dapat menghemat penggunaan pupuk Nitrogen anorganik sebanyak 25$50 \%$.

bahan organik lainnya dapat dijadikan sumber unsur hara sangat penting bagi tanah maupun tanaman untuk mempertahankan kesuburan tanah dan meningkatkan produksi tanaman.

juga sebagai indicator pertumbuhan juga sebagai data penunjang untuk menjelaskan proses pertumbuhan yang terjadi seperti pada pembentukan biomassa tanaman, dijelaskan pula bahwa pengamatan daun dapat didasarkan atas fungsinya sebagai penerima cahaya dan alat fotosintesis.

tanah masam antara lain inseptisol, ultisol dan andisol mampu meningkatkan $\mathrm{pH}$ tanah dan mampu menurunkan $\mathrm{Al}$ tertukar tanah. Peningkatan $\mathrm{pH}$ tanah terjadi apabila bahan organik telah terdekomposisi lanjut (matang) karena bahan organik yang telah termineralisasi akan melepaskan mineralnya berupa kation-kation basa. Hal ini membuktikan bahwa penggunaan kompos memberikan pengaruh lebih baik terhadap karakteristik tanah masam dibanding pengapuran. 


\section{KESIMPULAN}

Hasil penelitian dapat disimpulkan sebagai berikut :pH 7,17, N 2,57\%, P bahwa analisis kimia ( $\mathrm{pH}, \mathrm{N}, \mathrm{P}, \mathrm{K})$ $0,34 \%$, $\mathrm{K} \quad 0,03 \%$. kompos Azolla mycrophyllaadalah

\section{DAFTAR PUSTAKA}

Badan Tenaga Nuklir Nasional, 2010. Kelompok Pemupukan dan Nutrisi Tanaman. PATIR-BATAN, Jakarta. www.batan.go.id/patir/pert/pe mupukan/pemupukan.html. Diakses tanggal 13 Januari 2018.

Fitrai.E, 2015. Azolla Tanaman Paku Yang Menguntungkan Padi Sawah. nad.litbang.pertanian.go.id. Diakses tanggal 13 Januari 2018.

Hakim.N, Y.Nyakpa, Lubis, Nugroho.S.G, Diha.A, Go Ban Hong, Bailey, 1986. Dasar-Dasar Ilmu Tanah. Unila Press

Hardjowiegeno, 1987. Dasar-Dasar Ilmu Tanah. IPB Press

Huda,M.S, Widaryanto,E dan Nugroho,A, 2016. Pengaruh Beberapa Dosis Kompos Azolla Segar Pada Pertumbuhan dan Hasil 2 Varietas Tanaman Wortel (Daucus carotta). Jurnal Produksi Tanaman. Vol 4 No.6 September 2016 :431 437.

Nazaruddin, 2003. Budidaya dan Pengaturan Panen Sayuran Dataran Rendah, Penebar Swadaya. Jakarta

Putra.D.F, Soenaryo, Setyono.Y.T, 2013. Pengaruh Pemberian Berbagai Bentuk Azolla dan Pupuk N Terhadap Pertumbuhan dan Hasil Tanaman Jagung Manis (Zea mays saccharata). Jurnal Produksi Tanaman Vol.1

Sarief. 1988. Ilmu Tanah Pertanian. Pustaka Buana. Bandung

Suntoro, 2003. Peranan Bahan Organik Terhadap Kesuburan Tanah dan Upaya Pengelolaannya. UNS Press. Surakarta 